\title{
Officials of the Šamaš Temple of Sippar as Contract Witnesses in the Old Babylonian Period ${ }^{1}$
}

\author{
by Michel Tanret and Guido Suurmeijer - Ghent
}

Little is known about the organisation of the Šamaš temple in Old Babylonian Sippar, the Ebabbar. This is due to the fact that the vast majority of attestations of the temple officials of the Ebabbar are to be found in the witness lists of contracts. In these lists they occur together, as a group. The present article analyzes the formative stages of this group of witnesses, shedding light on institutional hierarchy, succession into temple offices, and the sealing practice of the time.

\section{Introduction}

The present article is a first foray in the rich, nearly unexplored forests of Old Babylonian witness lists and their composition and evolution through time, in combination with a study of the seal use of these witnesses. The witness lists as such have never been studied. C. Wilcke (1983) was one of the first to correlate the order of the names in a document with the order of sealing. F. Blocher (1992) and B. Teissier (1998) essentially studied seal impressions but also devoted attention to their place on the document in relation with the role of the seal owners or users in the document. M. Tanret (2010) did this extensively for the seals of the Old Babylonian šangûm of Šamaš and some other temple functionaries. The gist of the matter is that when a party to a contract seals, he/she goes first, sealing on the upper edge of the tablet envelope or at the top of its left edge. The first witnesses seal just beneath them, and further ones either do not seal or do so often without much order.

The present study starts not from the seal impressions but from the witness lists and will devote some interest to the seals that are involved. As a

1 This article is the result of research undertaken within the framework of the Interuniversity Pole of Attraction Programme VI/34 - Belgian State. Federal Office for Belgian Science Policy. Names of Old Babylonian kings will be abbreviated as follows: $\mathrm{Im}=\mathrm{Im}$ merum; Bti = Buntahtun-ila; Sle = Sumu-la-el; Sa = Sabium; AS = Apil-Sîn; Sm = Sînmuballit. The authors thank James Armstrong who read the manuscript and markedly improved its English. All seal drawings have been excellently drawn and digitally produced by E. Smekens who, once more, deserves our lasting gratitude. All seals drawings are printed at a scale of $150 \%$. 
first small test case, a quite obvious but hitherto unexamined group of people reoccurring within a number of witness lists will be explored.

The witness lists of some early Old Babylonian documentary texts from Sippar $^{2}$ contain a small group of persons, always occurring together ${ }^{3}$, often in the same order and, apart from some rare exceptions, without patronymic and title, whereas the other witnesses regularly have one or both (if not on the tablet, then usually on the case). This group is mostly found at the beginning of the witness list, occasionally it occurs further down but is still easily identifiable by the absence of a father's name or title. Through time the group evolves; new names appear in it as older ones disappear. Indications can be found that this group consists of people working for the main temple of Sippar: the Ebabbar of the god Šamaš. 4

We will try to identify the people belonging to this group and trace the changes that it underwent through time. Apart from the rare addition of a title to their name in the witness lists, essential information is to be found in their seal legends. Not only do the legends reveal the name of their father, but they most often also specify their title. These titles are overseer of the naditum priestesses (UGULA LUKUR ${ }^{\mathrm{d} U T U}$ ) and doorkeeper of the gagûm-precinct (ì.DU $\mathrm{D}_{8}$ sa gagîm). The chariot driver ${ }^{5}$ of the Šamaš temple and of the gagûm (RÁ.GABA NÍG É dUTU / NÍG É ga-gi-im) are attested only in the earlier documents. A title appearing sporadically is that of courtyard sweeper (KISAL.LUH). ${ }^{6}$ In a number of cases the first šangûm of Šamaš and, later the second šangûm, as well, head the list, always with their title, as befits šangûms. These are all known temple offices of that time.

We will examine the place and order of the seal impressions on the envelope in order to see whether they correspond to the place and order of the names in the witness list. If a correspondence is found, this will be interpreted as a proof of the conscious ordering of (at least this part of) the witness list.

Although only a few temple offices are concerned, the group of officials can consist of up to eight people because there was more than one chariot

2 This is Sippar-Jahrurum, where the Šamaš temple is located.

${ }^{3}$ CT 8, 44a is an exception where the group is split up (cf. infra).

${ }^{4}$ Whether they were employed full-time or were prebendaries is a very important question (van Driel 2002, 35) but will not be treated in this article for lack of evidence in the early texts discussed here.

5 A translation proposed instead of 'messenger' in Sallaberger (2003/4, 52 n. 14).

6 See van Koppen (2001) for the latest comments on this title. 
driver or doorkeeper at the same time. Another interesting particularity is that the development of the group can be traced in enough detail to show that these functions were sometimes hereditary.

Although this phenomenon can be observed over ca. 250 years, from the reign of Immerum to that of Ammi-saduqa, we have chosen to limit our time frame to the earliest texts of Old Babylonian Sippar in order not to exceed the limits of an article. These texts date from the reigns of kings Buntahtun-ila, Immerum ${ }^{7}$ and Sumu-la-el (1784-1749 BCE ${ }^{8}$ ) up to and including the reign of Sabium (1748-1735 BCE). We chose these particular chronological limits for two reasons:

- they contain the starting point of the group

- this period is long enough to show the first successions and changes

Within this time span we have a corpus of thirty-two documents, either tablet alone or tablet and case9.

\section{Prolegomena chronologica}

Before we start our investigation we will have to clarify the chronological order of the texts within our corpus since this is the basis upon which it rests. We have three kinds of chronological markers.

\section{Year name}

This is not a simple matter because only six of our thirty-two texts have an identifiable year name. One is dated to the reign of the local Sippar king Buntahtun-ila (mu níg bu-un-/tah-〈tu〉-un-i-la lugal.e, BDHP 31/CT $45,1)$. Unfortunately, the length of his reign is not known and we have no way to situate him chronologically, other than a double oath to him and the Babylonian king Sumu-la-el (cf. infra). The other five are all dated to Sabium, respectively to his years $2,10,11,12$ and 13.10 Two more have year names that cannot be identified. ${ }^{11}$ One of these has a year name men-

7 Two local rulers of Sippar, before Babylon took over, cf. Charpin (2004, 91-94; $83 \mathrm{n}$. 287).

8 According to the short chronology as developed in Gasche et al. (1998). The difference with the commonly used but erroneous middle chronology is 96 years.

9 Isolated officials of the Ebabbar exceptionally appear as witnesses, such as in CT 6, 42a (T) / MHET 23 (C). These texts are not included in our corpus.

$10 \mathrm{CT} 6,40$ c is Sa 2; CT 6, 47a/MHET 44 is Sa 10; BDHP 22/23 is Sa 11; CT 2, 50/MHET 45 is Sa 12; CT 2, 3 is Sa 13.

11 CT 4, 50a; CT 4, 47b. 
tioning the death of Ị̇i-Sumu-abum; this has hypothetically been attributed to Immerum. ${ }^{12}$

Oath

All texts can at least be dated by the oath to the reigning king, except four that have neither a date nor an oath. ${ }^{13}$ Kings mentioned in the oaths within the time span under consideration are: Buntahtun-ila and Immerum, both kings of Sippar, and the two first kings of Babylon who had incorporated Sippar into their realm: Sumu-la-el and Sabium. The problem here is that the first three have partially overlapping reigns (Charpin 2004, 83 and note 287). Prosopography comes to the rescue here with the careers of the sangums and the overseer of the naditum priestesses of the Ebabbar, our third chronological marker.

Šangûms of the Ebabbar and overseer of the naditum-priestesses

The careers of the first and second šangûms of the Ebabbar provide chronological information supplementing that of the year names and the oaths. It has been established that there was only one first šangûm at a time, and that there was a father-to-son succession between them. Similarly, there was only one second šangûm acting at any one time (Tanret 2010, 93 sqq.). The names and dates of the first šangûms of interest to us here are the following: - Annum-pî-Šamaš, attested in texts with an oath to Immerum or with a combined oath to this king and Sumu-la-el

- his son Šamaš-tappašu, attested in texts with an oath to Sumu-la-el only, as well as in texts without year name or oath

- the son of Šamaš-tappašu, Lipit-Ištar, is attested in texts dated by the oath to Sumu-la-el and to Sabium

The group of texts so determined can be ordered further according to the occurrence of the overseer of the naditum-priestesses, first Būr-Nunu, and after him his son Ilabrat-bāni.

As a last means of ordering, the succession of second šangûms can be used. The first of them, Išar-Šamaš, starts his career at some time during Sabium's reign, and is attested in texts with an oath to and/or a year name of this king.

12 CT 4, 47b. Cf. Harris (1975, 3 n.6) and Charpin (2001, 90). This year name cannot be one of Iși-sumu-abum's own.

13 CT 33, 42; CT 33, 43; MHET 784 and MHET 567. They can be roughly dated by their witness lists. 
The one text (BDHP 31/CT 45, 1) with an oath and year name to king Buntahtun-ila does not mention a first šangûm or an overseer of the naditum priestesses. The fact that its oath also mentions Sumu-la-el helps a little but other criteria will be adduced below to further classify it.

Combining these criteria our corpus can be chronologically classified by king, šangûm and overseer of the naditums. This leads to a division in seven chronological stages:

\begin{tabular}{|c|c|c|c|c|}
\hline & King & First šangûm & Second šangûm & Overseer of the naditums \\
\hline 1. & $\begin{array}{l}\text { Immerum + } \\
\text { Sumu-la-el }\end{array}$ & Annum-pî-Šamaš & - & Būr-nunu \\
\hline 2 . & Sumu-la-el & Šamaš-tappašu & - & Būr-nunu \\
\hline 3. & Sumu-la-el & Lipit-Ištar & - & Būr-nunu \\
\hline 4. & Sabium & Lipit-Ištar & - & Būr-nunu \\
\hline 5. & Sabium & Lipit-Ištar & - & Ilabrat-bāni \\
\hline 6 . & Sabium & Lipit-Ištar & Išar-Šamaš & Ilabrat-bāni \\
\hline 7. & [Sabium $\left.{ }^{14}\right]$ & Lipit-Ištar & Sîn-ennam & Ilabrat-bāni \\
\hline
\end{tabular}

It is difficult to attain a more detailed ordering. As will be readily apparent from the tables below it is not always possible to determine the chronological order within each stage.

\section{The formative stages}

\section{The first stage (Immerum and Annum-pî-Šamaš)}

Defining the stage

The presence of the šangûm Annum-pî-Šamaš (ApŠ) and the Immerum date are the criteria defining this stage. These allow us to single out five texts.

In the following tables, the officials' titles are added when given in the text or on the case. ${ }^{15}$ The first and last attestations of an official are indicated with "BEGIN" and "END", respectively, and cells containing a first attestation within a stage are given a thick border. The numbers given in front of the names are: the place in the witness list of the tablet/the case, a question mark indicating the absence because the list is broken, a dash the complete absence in a list.

\footnotetext{
14 The second šangûm Sîn-ennam is attested in Sa 14 and his successor from the first year of the next king, Apil-Sinn, onwards. This allows us to conclude that all texts mentioning this Sin-ennam must be dated under Sabium towards the end of his reign.

15 The abbreviations used are: $\mathrm{O}$ (verseer), C(hariot) $\mathrm{D}$ (river) and $\mathrm{D}$ (oorkeeper).
} 


\begin{tabular}{|c|c|c|c|c|c|c|}
\hline $\begin{array}{l}\text { CT } 4,47 b / \\
\text { BM } 80338\end{array}$ & Im & - & $\begin{array}{l}\text { 8) Ilum-mušallim } \\
\text { D }\end{array}$ & $\begin{array}{l}\text { 9) Damu-galzu } \\
\text { DUB.SAR }\end{array}$ & $\begin{array}{l}\text { 10) Šamaš- } \\
\text { SUG.A-niš̄̄ } \\
\text { CD }\end{array}$ & 11) Lū-dāri \\
\hline BDHP 14 & Im oath & $\begin{array}{l}1 / ?) \\
\text { ApŠ }\end{array}$ & $\begin{array}{l}\text { 2/?) Ilum-mušallim } \\
\text { D + seal }\end{array}$ & $\begin{array}{l}\text { 3/?) Damu-galzu } \\
\text { CD }\end{array}$ & & \\
\hline VS $8,4 / 5$ & Im oath & $\begin{array}{l}1 /-) \\
\text { Apš }\end{array}$ & $\begin{array}{l}\text { 2/-) Ilum-mušallim } \\
\text { D + seal }\end{array}$ & $\begin{array}{l}\text { 3/-) Damu-galzu } \\
\text { CD }\end{array}$ & $\begin{array}{l}\text { 4/-) Lū-dāri } \\
\text { CD }\end{array}$ & $\begin{array}{l}\text { 5/-) Šamaš- } \\
\text { SUG.A-nišī } \\
\text { CD }\end{array}$ \\
\hline CT $4,50 \mathrm{a}$ & $\begin{array}{l}\operatorname{Im}+ \\
\text { Sle }^{16}\end{array}$ & $\begin{array}{l}\text { 7) } \\
\text { ApŠ }\end{array}$ & $\begin{array}{l}\text { 8) Imlik-Sîn nar } \\
\text { BEGIN / END }\end{array}$ & $\begin{array}{l}\text { 9) Ilum-mušallim } \\
\text { D }\end{array}$ & & $\begin{array}{l}\text { 10) Lū-dāri } \\
\text { CD END }\end{array}$ \\
\hline MHET 7 & Im oath & $\begin{array}{l}1 /-) \\
\text { ApŠ }\end{array}$ & $\begin{array}{l}\text { 2/-) Būr-Nunu }{ }^{17} \\
\text { BEGIN }\end{array}$ & $\begin{array}{l}\text { 4/-) Ilum-mušallim } \\
\text { + seal D }\end{array}$ & $\begin{array}{l}\text { 5/-) Damu- } \\
\text { galzu } \\
\text { CD }\end{array}$ & \\
\hline
\end{tabular}

The order of the texts

CT 4, 47b (the text dated by the death of İsi-Sumu-abum, mu i-și-su$m u-a-b u-u m$ ba.ú š, which, as explained above, we take to be an Immerum year name), BDHP 14 and VS 8, 4/5 have been placed at the top of this stage because there is not yet a witness mentioned between the šangûm and Ilum-mušallim. The singer (NAR) Imlik-Sîn is the first one to appear between them (CT 4, 50a). We have placed this text before MHET 7 because there the son of Imlik-Sîn, Būr-Nunu, occupies this second position, which he will hold for a long time. He is the first known overseer of the naditum-priestesses of the god Šamaš (UGULA LUKUR dUTU).

The composition of the group

Already in this earliest stage we see a phenomenon that is very common throughout our period: when the šangûm is not a witness, the other temple officials move as a group to lower positions in the witness list (CT 4, 47b / BM 80338). CT 4, 50a seems to be an exception in this regard, since there is a šangum leading the temple group but the whole group is placed at the end of the witness list, an inversion of what we would expect. The first witness is a neighbour of the field that is sold in this contract. The order may have been different on the (now lost) case, which is usually more carefully composed since it carries the outer, visible, text.

16 Oath by Im and Sle, year name of Im: mu egir li.li.ìz a.a.bi / dingir babbar.ra mu.na.an.dím

17 The third witness (3/-) is Ëriš-ilum, whom we know to be a brother of Būr-Nunu thanks to this text only. 
As can be observed in the table, apart from the šangûm there is a main group of four people nearly always appearing in the same order (but not always all of them) in our earliest texts: Ilum-mušallim, Damu-galzu, Šamaš-SUG.A-nišì and Lū-dāri - one doorkeeper and three chariot drivers, respectively. Once, the latter two exchange places. Only at the end of the stage the father and son Imlik-Sîn and Būr-nunu appear.

Who are these people?

The sangums will not be discussed here since they are the object of an exhaustive study (Tanret 2010). In our presentation of the other temple officials, we will restrict ourselves to their (period of) attestation, their father or predecessor and their son or immediate successor. When known, we will give the seal of each official.

\section{Imlik-Sîn ${ }^{18}$}

Attestations:

Title:

$1(\mathrm{Im} / \mathrm{Sle})$.

Predecessor/father: Unknown.

Successor/son: Būr-Nunu, the first overseer of the naditum-priestesses.

Daughter:

Erišti-Aja, a female overseer of the naditum-priestesses; not a regular witness among the group of temple officials.

Another son: $\quad \bar{E}$ riš-ilum (MHET 719 ), no title known.

Seal: Unknown.

In the one text where he appears, he comes between the first šangûm and the doorkeeper Ilum-mušallim (who is second witness after the šangûm in two other texts). This position is meaningful since his son BūrNunu will occupy the same place.

Būr-Nunu

Attestations:

Title:

12 in total (Im - Sa, some 40 years), all within our present corpus. Overseer of the naditum-priestesses according to five texts in our corpus, as well as to his seal.

Predecessor and father: Imlik-Sîn, NAR.

Successor/son: Ilabrat-bāni, overseer of the nadìtum-priestesses like his father.

Seal: Rolled on six cases, all Sle ${ }^{20}$ (= Blocher 1992 no 73). We give a new reconstruction here:

\footnotetext{
18 Harris $(1975,175)$, wrongly reads his name as Imgur-Sîn.

19 His presence can be reconstructed in CT 45, 2, cf. infra.

20 CT 8, 28a, BM 82350, CT 48, 31, MHET 18, VS 8, 13 and CT 45,2.
} 


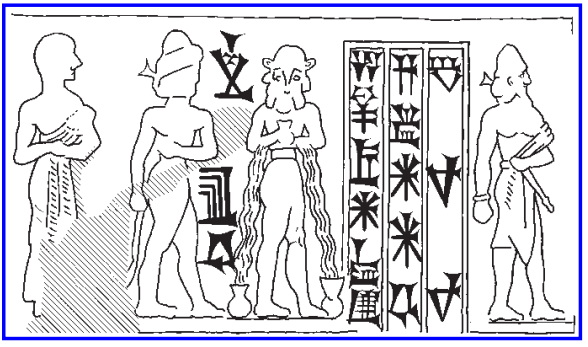

bur-nu-nu

UGULA NIN.DINGIR d UTU ${ }^{21}$

DUMU im-lik-d EN.ZU

$\mathrm{IR}_{11}$ É.BABBAR

\section{Ilum-mušallim}

Attestations:

Title:

Predecessor/father:

Successor and son:

Seal:
6 (Im - Sle/Bti, some 40 years), all within our present corpus.

Doorkeeper of the gagûm-precinct (CT 4, 50a, and his seal).

Unknown.

Amurrum-bāni, doorkeeper of the gagûm-precinct.

Attested three or four times, during Im and $\mathrm{Sle}^{22}$ (= Blocher 1992, no 26 , not drawn there). We give our reconstruction here: ${ }^{23}$

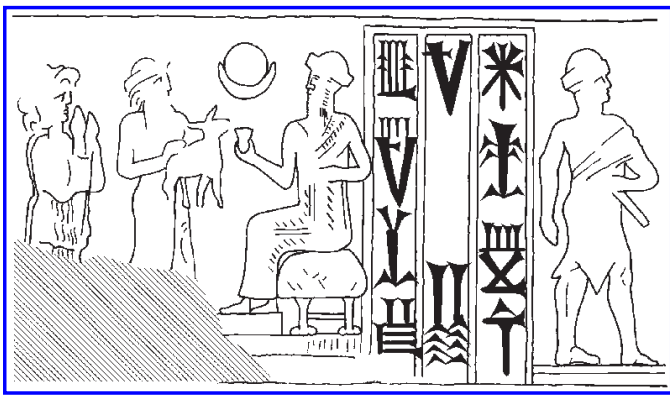

DINGIR- $m u-s ̌ a-l i m$

İ. $\mathrm{DU}_{8}$

KÁ ga-gu-um

In the earliest documents Ilum-mušallim comes after the šangûm and the singer or the overseer. In the absence of both he can be the first witness of the group, in the absence of only the overseer he becomes second witness.

\section{Damu-galzu}

Attestations:

Title:

Predecessor/father:
13 (Im - Sle, some 40 years), all within our present corpus.

Once a scribe (DUB.SAR in CT 4, 47b 24 ); a court sweeper (KISAL.LUH) of the Šamaš temple (according to his undated seal); a chariot driver of the Šamaš temple (RÁ.GABA NÍG É dUTU, MHET 7).

Unknown.

${ }^{21}$ Stol (2000) has shown that NIN.DINGIR on seals corresponds to LUKUR in the texts.

22 BDHP 14 (Im), VS 8, 4/5 (Im), CT 45, 1 (case of BDHP 31) (Sle/Bti), and perhaps also on MHET 7 (Im).

23 Cf. Tanret $(2010,79)$.

${ }^{24}$ We are certain that this is our Damu-galzu as he appears here amidst other known temple officials of the same period. We can identify nearly all the other occurrences of the name as referring to this same person. 
Successor and son: Adad-rēmēni, chariot driver, later doorkeeper of the gagûm-precinct.

Seal: $\quad$ As courtyard sweeper (KISAL.LUH) of the Ebabbar attested once (undated). ${ }^{25}$ We have no seal of him as chariot driver:

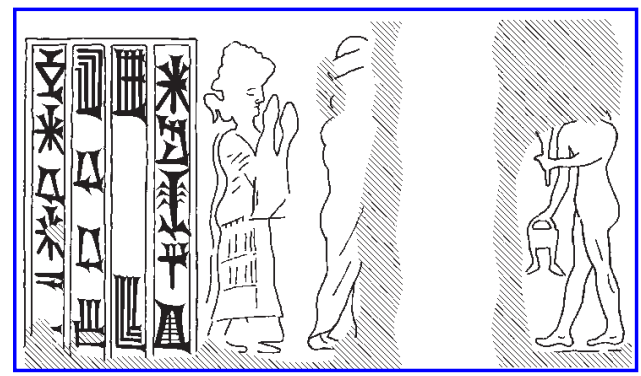

\author{
${ }^{\mathrm{d}} d a-m u-\mathrm{GAL} . \mathrm{ZU}$ \\ KISAL.LUH \\ É.BÁBBAR.RA \\ İR ${ }^{\mathrm{d}} \mathrm{UTU}{ }^{\mathrm{d}} a-{ }^{\mathrm{r}} a$
}

A study of the unidentified seals on the six envelopes in our corpus where Damu-galzu is a witness did not yield any candidates for another seal of his. His chariot driver (RÁ.GABA) seal - we assume that he had one $^{26}$ - remains unknown to us.

\title{
Šamaš-SUG.A-nišĩ ${ }^{27}$
}

Attestations: $\quad 8$ (Im - Sle, some 40 years), all within our present corpus.

Title: Chariot driver of the Šamaš temple (RÁ.GABA Níg É dUTU, CT 45, 1, the case of BDHP 31).

Predecessor/father: Unknown.

Successor/son: Unknown.

Seal: Unknown.

As a chariot driver he consistently comes after Damu-galzu until, during our second stage, he is a witness before him in a number of texts.

\section{Lū-dāri}

Attestations: $\quad 3$ (Im - Sle, some 40 years), all in this first stage.

Title: Chariot driver (RÁ.GABA, CT 4, 50a).

Predecessor/father: Unknown.

Successor/son: Unknown.

Seal: Unknown.

As a witness he is consistently the last one of the temple officials.

25 On TCL 1, 185 (undated fragment).

26 There is no a priori reason why as RÁ.GABA Damu-galzu would not have had a seal. His son Adad-rēmēni owned a seal which states his title as RÁ.GABA (on BM 82513, the case of CT 6, 40c, one of our texts).

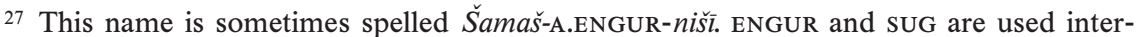
changeably. Cf. Stamm $(1939,228)$. W. Sallaberger (private communication) proposes a reading Šamaš-nār-nišs which must certainly be taken into consideration. 
The sequence within the group

The sequence of titles is: šangûm - singer/overseer - doorkeeper chariot driver (up to three).

Sealing pattern

For this stage we have the seals of members of the group on three documents. The order in which these seals are applied is the same for all three documents, and is continued into the next stage.

On BDHP 14 the first šangum seals on the upper edge of the envelope, the most important place at that time. The doorkeeper Ilum-mušallim (second witness) seals after him, at the top of the left edge. On VS 8, 5 the šangûm seals on the left edge (maybe also on the upper edge but this is broken) and the doorkeeper Ilum-mušallim (second witness) seals on the same edge, below him. On MHET 7 the šangûm may have sealed on the now lost upper edge, the overseer Būr-Nunu (second witness) may have sealed on the left edge, also lost. The doorkeeper Ilum-mušallim (fourth witness, after Būr-nunu's brother Ėriš-ilum) seals on the lower edge. The order of the sealings of the temple officials is thus: first official - upper or top left edge, second official - left edge, third official - lower edge.

The second stage (Sumu-la-el and Šamaš-tappašu)

\section{Defining the stage}

The year name or oath to king Sumu-la-el and the presence of the šangûm Šamaš-tappašu (Št in the table below) are the criteria defining this stage. A number of texts have been added, lacking one or even both these chronological markers, for reasons explained below.

\begin{tabular}{|l|l|l|l|l|l|l|}
\hline $\begin{array}{l}\text { BDHP 31 / } \\
\text { CT 45, } 1\end{array}$ & $\begin{array}{l}\text { Bti + } \\
\text { Sle }^{28}\end{array}$ & & $\begin{array}{l}\text { 5/5) Ilum-mušal- } \\
\text { lim + seal } \\
\text { D END }\end{array}$ & $\begin{array}{l}\text { 6/6) Damu-galzu } \\
\text { CD }\end{array}$ & $\begin{array}{l}\text { 7/7) Šamaš-SUG.A-nišī } \\
\text { CD }\end{array}$ \\
\hline JCS 30, 235E & $\begin{array}{l}\text { Sle } \\
\text { oath }\end{array}$ & & $\begin{array}{l}\text { 1) Damu-galzu } \\
\text { CD }\end{array}$ & $\begin{array}{l}\text { 2) Šamaš- } \\
\text { sUG.A-nišĩ } \\
\text { CD }\end{array}$ & $\begin{array}{l}\text { 3) Amurrum-bānī } \\
\text { D BEGIN29 }\end{array}$ \\
\hline CT 6, 30a & $\begin{array}{l}\text { Sle } \\
\text { oath }\end{array}$ & 1) Št & 2) Būr-nunu & $\begin{array}{l}\text { 3) Šamaš- } \\
\text { sug.A-nišĩ } \\
\text { D? }\end{array}$ & $\begin{array}{l}\text { 4) Damu-galzu } \\
\text { CD }\end{array}$ & $\begin{array}{l}\text { 5) Amurrum-bāni } \\
\text { D }\end{array}$ \\
\hline
\end{tabular}

28 Oath by Sle and Bti, the year name is Bti.

29 Followed by Erišti-Aja, female overseer of the naditum priestesses and sister of Būr-Nunu. 


\begin{tabular}{|c|c|c|c|c|c|c|}
\hline CT 33,42 & s.d. & & & $\begin{array}{l}\text { 1) Šamaš-SUG.A-nišī } \\
\text { D? }\end{array}$ & $\begin{array}{l}\text { 2) Damu-galzu } \\
\text { CD }\end{array}$ & $\begin{array}{l}\text { 3) Amurrum-bāni } \\
\text { D }\end{array}$ \\
\hline CT 33,43 & s.d. & & & $\begin{array}{l}\text { 1) Šamaš-SUG.A-nišī } \\
\text { D? }\end{array}$ & $\begin{array}{l}\text { 2) Damu-galzu } \\
\text { CD }\end{array}$ & $\begin{array}{l}\text { 3) Amurrum-bāni } \\
\text { D }\end{array}$ \\
\hline MHET 784 & s.d. & & & $\begin{array}{l}\text { 1) Šamaš-SUG.A-nišì } \\
\text { D? END }\end{array}$ & $\begin{array}{l}\text { 2) Damu-galzu } \\
\text { CD }\end{array}$ & $\begin{array}{l}\text { 3) Amurrum-bāni } \\
\text { D }\end{array}$ \\
\hline CT 2,35 & $\begin{array}{l}\text { Sle } \\
\text { oath }\end{array}$ & 1) $\breve{S t}$ & 7) Būr-nunu & & $\begin{array}{l}\text { 2) Damu-galzu } \\
\text { CD }\end{array}$ & $\begin{array}{l}\text { 3) Amurrum-bāni } \\
\text { D }\end{array}$ \\
\hline CT 45,2 & $\begin{array}{l}\text { Sle } \\
\text { oath }\end{array}$ & $-/ 1) \check{S} \mathrm{t}$ & \multicolumn{2}{|c|}{$\begin{array}{l}\text {-/2) Būr-nunu }{ }^{30} O \\
\text {-/4) } \\
\text { Erišs-ilum }\end{array}$} & & \\
\hline
\end{tabular}

The order of the texts

On BDHP 31 / CT 45, 1 there is no šangûm witness nor is there an overseer of the naditum priestesses. It has a double oath to the kings Buntahtun-ila and Sumu-la-el and a year name of Buntahtun-ila: mu níg bu$u n-/ t a h-\langle t u\rangle-u n-i-l a$ lug al.e. The contemporaneity with Sumu-la-el could place it in stage 1 as well as here. We have arbitrarily chosen to place it here, where it must be the oldest text because it is the last one in which Ilum-mušallim appears. In all but one of the other texts of this stage his son and successor Amurrum-bāni appears.

The absence of a šangûm at the head of the group is the reason that the group is placed lower in the witness list.

Four other texts (CT 6, 30a; CT 33, 42; CT 33, 43 and MHET 784) have a consistent order for the members of our group. Three of these (CT 33, 42; CT 33, 43 and MHET 784) mention neither an oath by the king, nor a šangûm, but they belong together since they document the business of a woman named Innabatum. ${ }^{32}$ Because they are witnessed by the same members of our group in the same order, we have grouped them together with CT 6,30a, also showing this same order but securely dated to this stage by oath and šangûm. These four texts are the last attestations of Šamaš-SUG.A-nišī.

30 The second witness here must be Būr-Nunu, the fourth his brother Ëriš-ilum (Tanret 2010, 83).

31 CT 45, 2 erroneously reconstructs the name of a second šangûm as the second witness, and Būr-Nunu as fourth. There was, however, at this time no second šangûm yet, and the second witness must be [Būr-Nunu UGULA LUKUR] ' ${ }^{\mathrm{N}} \mathrm{I}^{\prime}{ }^{\mathrm{T}} \mathrm{d} \mathrm{UTU}$. The traces which Pinches

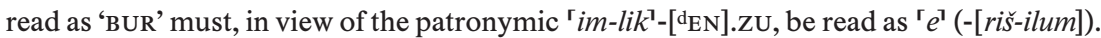

32 Last witness in all three texts is the female scribe Inanna-ama.mu, daughter of Ajabbatâabum. The documents' contents are strongly related: the same woman, Innabatum, leases out fields for cultivation. We believe that these three texts belong together chronologically within a rather limited time frame. 
The placing of JCS 30, 235E before the aforementioned four texts is explained below.

We have inserted CT 2, 35 at the end because it shows the same order of Damu-galzu followed by Amurrum-bāni as the preceding texts but they are no longer preceded by Šamaš-SUG.A-nišī, who has disappeared by now.

CT 45, 2 does not list anyone from the temple except for the sangûm and the overseer, so we have added it at the end but it could be placed anywhere in this stage.

The sequence within the group

The temple officials Ilum-mušallim, Damu-galzu and Šamaš-sug.A-nišī continue to witness together. The interesting point is that for the first time we now see a succession of father to son in the same office (the sequence Imlik-Sîn - Būr-Nunu did not involve the same office). This happens when the doorkeeper Ilum-mušallim is succeeded by his son Amurrum-bāni. An unexpected consequence is a change of the order within the group. Amurrum-bāni does not assume his father Ilum-mušallim's place at the head of the group, before Damu-galzu and Šamaš-SUG.A-nišì, but instead follows after these two chariot drivers. A son succeeding to his father here (temporarily) drops in the hierarchy although he holds the same title. It seems that seniority could be a more decisive criterion than title.

This stage also shows another interesting deviation from the order of witnesses as found in the first stage. This deviation reflects a change in the hierarchy which allows us to establish the documents' chronological order in more detail, as we will now explain.

The change is in the order of Damu-galzu and Šamaš-SUG.A-nišĩ. Damu-galzu precedes his colleague chariot driver in the first stage and in two documents of the second stage (BDHP 31/CT 45, 1 and JCS 30, $235 \mathrm{E}$ ). In the four remaining documents where they occur together, this order is inverted. The only explanation we can imagine is that ŠamašSUG.A-nišì, originally chariot driver, would have become a doorkeeper towards the end of his career. Unfortunately the texts of this stage provide neither titles nor seals to ascertain this. If true, this could be linked to his age, since there seems to be a connection between this title and older people. ${ }^{33}$ As a doorkeeper he would then take over the place of Ilummušallim before the latter's son, Amurrum-bāni, ascends to this place.

JCS 30, 235E which does not (yet) show this inversion, must then be older than the other four texts, which is why we have placed it before them.

33 C. Wilcke $(1998,35)$ mentions janitors (İ.DU 8 ) specifically qualified as old in the Ur III period. 
Who are these people?

Amurrum-bāni

Attestations:

Title:

Predecessor/father:

Successor/son:

Seal:
13 in total (Sle - post-SA 2), all within the present corpus.

Doorkeeper (ì.DU $)_{8}$ ); title attested only on his seal.

Ilum-mušallim, ì.DU (patronymic attested only on Amurrumbāni's seal).

Unknown.

Attested once ${ }^{34}$ under Sle (= Blocher 1992 no 81). Our reconstruction of the seal is reproduced below:

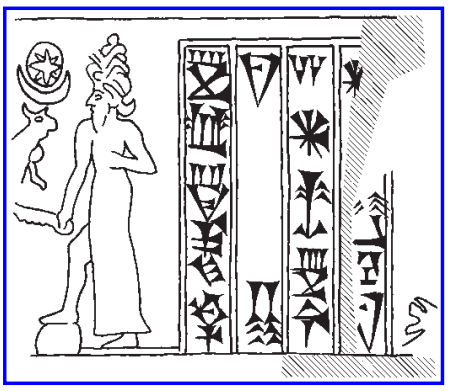

\author{
$\mathrm{r}_{\mathrm{d}}$ [MAR].TU-ba-ni \\ DUMU DINGIR-mu-ša-lim \\ Ì.DU 8 \\ ša KÁ ga-gi-im
}

\section{Sealing pattern}

On the only two envelopes that we have in the second stage (CT 45, 1 and CT 45,2), we can reconstruct the same pattern as in the first stage, from the upper edge/top left edge, over the left edge, to the lower edge. The table below gives an overview for the first two stages. ${ }^{35}$

\begin{tabular}{|l|l|l|l|l|l|l|}
\hline Text & & First witness & & Second witness & $\begin{array}{l}\text { Other } \\
\text { officials }\end{array}$ \\
\hline BDHP 14 & UE & $\begin{array}{l}\text { Annum-pî-Šamaš, } \\
\text { šangûm }\end{array}$ & LE top & $\begin{array}{l}\text { Ilum-mušallim, } \\
\text { İ.DU }\end{array}$ & - & \\
\hline VS 8, 4/5 & [UE] LE top & Annum-pî-Šamaš & LE & Ilum-mušallim & - & - \\
\hline MHET 736 & [UE] & Annum-pî-Šamaš & [LE] & $\begin{array}{l}\text { Būr-nunu, } \\
\text { UGULA LUKUR dUTU }\end{array}$ & LoE & $\begin{array}{l}\text { Ilum- } \\
\text { mušallim }\end{array}$ \\
\hline $\begin{array}{l}\text { BDHP 31 / } \\
\text { CT 45, 1 }\end{array}$ & - & - & - & - & Rev & $\begin{array}{l}\text { Ilum- } \\
\text { mušallim }\end{array}$ \\
\hline CT 45, 2 & [UE] & $\begin{array}{l}\text { Šamaš-tappašu, } \\
\text { šangûm }\end{array}$ & LE top & Būr-nunu & - & - \\
\hline
\end{tabular}

The fact that Ilum-mušallim sealed the reverse of the case CT 45, 1 is in keeping with the lower position of the entire group of officials in the witness list.

${ }^{34}$ CT 48, 31 (case of CT 8, 44a).

$35 \mathrm{UE}=$ upper edge; $\mathrm{LE}=$ left edge; LoE $=$ lower edge; Rev $=$ reverse. Straight brackets indicate that the seal must have been rolled on the now lost edge of the case.

36 Blocher $(1992,24)$ VI, has the seal scheme upside down. 
Since we have no sealing of Amurrum-bāni in these stages, we cannot verify whether his sealing location changes with respect to his father's as a reflection of his changed position in the witness lists.

The third stage (Sumu-la-el and Lipit-Ištar)

\section{Defining stage}

None of the texts of this stage is dated by a year name. The determining factors for the third stage are the oath by Sumu-la-el and the presence of the new first šangûm Lipit-Ištar (LI in the table below). This allows us to single out five texts.

\begin{tabular}{|c|c|c|c|c|c|c|c|}
\hline $\begin{array}{l}\text { CT } 8,44 \mathrm{a} / \\
\text { CT } 48,31\end{array}$ & \begin{tabular}{|l} 
Sle \\
oath
\end{tabular} & 4/1) LI & $\begin{array}{l}\text { 1/2) Būr-nunu } \\
\mathbf{O}\end{array}$ & $\begin{array}{l}\text { 6/7) Damu-galzu } \\
\text { CD }\end{array}$ & $\begin{array}{l}\text { 7/8) Amurrum- } \\
\text { bāni } \\
\text { + seal D }\end{array}$ & & \\
\hline $\begin{array}{l}\text { CT 6, 26a / } \\
\text { BM 17105 }\end{array}$ & $\begin{array}{l}\text { Sle + } \\
\mathrm{Sa}^{37} \\
\text { oath }\end{array}$ & 1/?) LI & $\begin{array}{l}\text { 2/?) Būr-nunu } \\
\mathbf{O}\end{array}$ & $\begin{array}{l}\text { 3/?) Damu-galzu } \\
\text { CD END }\end{array}$ & $\begin{array}{l}\text { 4/?) Amurrum- } \\
\text { bāni } \\
\text { D }\end{array}$ & 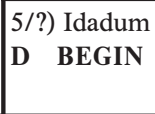 & \\
\hline \begin{tabular}{|l|} 
CT 2,33 \\
\end{tabular} & \begin{tabular}{|l|} 
Sle \\
oath
\end{tabular} & 1) $\mathrm{LI}$ & 2) Būr-nunu & $\begin{array}{l}\text { 3) Amurrum-bāni } \\
\text { D }\end{array}$ & $\begin{array}{l}\text { 4) Adad- } \\
\text { rēmēni } \\
\text { CD BEGIN }\end{array}$ & $\begin{array}{l}\text { 5) Idadum } \\
\text { D }\end{array}$ & \\
\hline CT 2, 34 & \begin{tabular}{|l|} 
Sle \\
oath
\end{tabular} & 1) $\mathrm{LI}$ & 2) Būr-nunu & $\begin{array}{l}\text { 3) Amurrum-bāni } \\
\text { D }\end{array}$ & $\begin{array}{l}\text { 4) Adad- } \\
\text { rēmēni } \\
\text { CD }\end{array}$ & $\begin{array}{l}\text { 5) Idadum } \\
\text { D }\end{array}$ & \\
\hline MHET 18 & \begin{tabular}{|l} 
Sle \\
oath
\end{tabular} & 1/1) LI & $\begin{array}{l}\text { 2/2) Būr-nunu } \\
\mathbf{O}\end{array}$ & $\begin{array}{l}\text { 3/3) Amurrum- } \\
\text { bāni } \\
\text { D }\end{array}$ & $\begin{array}{l}\text { 4/4) Adad- } \\
\text { rēmēni } \\
\text { CD }\end{array}$ & $\begin{array}{l}\text { 5/5) Idadum } \\
\text { D }\end{array}$ & $\begin{array}{l}\text { 6/?) } \\
\text { Šamaš- } \\
\text { liț̣ul } \\
\text { BEGIN }\end{array}$ \\
\hline
\end{tabular}

The order of the texts

The last two attestations of Damu-galzu come first because they continue the preceding stage. The ones with Amurrum-rēmenni follow because they connect to the next one.

This places the doorkeeper Idadum and Šamaš-lițul (without title but maybe also a doorkeeper, cf. infra) at the end of the stage.

The sequence within the group

The šangûm and the overseer always head the group. In the previous stage we saw that when Amurrum-bāni took over his father's title, he

37 The oath is broken on the tablet copied in CT 6; on the case BM 17105, photographed by $\mathrm{M}$. Vandierendonck, it can be clearly read. 
occupied the last position. This ends when Damu-galzu's career comes to an end. From now on, in stage three and part of stage four, Amurrum-bāni will occupy the proper position of a doorkeeper, immediately after the overseer of the naditum priestesses, Būr-nunu.

When Damu-galzu is succeeded by his son Adad-rēmēni, the latter takes over his father's title of chariot driver and his rank in the witness list (cf. diagram on p. 106). This is surprising in comparison with the succession by Amurrum-bāni, who had started at the bottom of the group. Adad-rēmēni's higher starting position is not prompted by age since he will have a long career afterwards, at the end of which he will even become a doorkeeper. There must be some other factor at work here, in no way expressed in the texts, and ungraspable for us.

Adad-rēmēni is followed by Idadum, a doorkeeper, and Šamaš-lițul, presumably a doorkeeper as well, two newcomers ${ }^{38}$ not linked to previous office holders in the temple as far as we know. From now on there will always be doorkeepers at the end of the list, only occasionally followed by a courtyard sweeper.

Who are these people?

\section{Adad-rēmēni}

Attestations:

Title:

Predecessor/father: 52 (Sle - Sm), 15 in the present corpus.

Successor/son: Chariot driver (RÁ.GABA: MHET 66 dated AS; seal A, infra); later doorkeeper (İ.DU ${ }_{8}$ ) also attested once (MHET 61 dated AS).

Damu-galzu, chariot driver (RÁ.GABA).

Kalūmum, probably doorkeeper of the gate of the gagûm-precinct (İ.DU ${ }_{8}$ KÁ gagîm).

Seal:

Seal A with a four-line legend (= Blocher 1992 no 100; attested only once, on CT 6, 40c dated Sa). Seal B with a three-lines legend (= Blocher 1992 no $\left.166(=264)^{39}\right)$ attested five times (MHET 35 and VS 8, 13, both Sa; CT 47, 7a and CT 8, 29A both AS; CT 47, 11a, $\mathrm{Sm})$. We give a new reconstruction of both seals:

38 Šamaš-littul's father Pala-Sîn may have been close to temple circles. There is a Pala-Sîn witness in VS 8, 4 dated Im, but without title or patronymic. His appearance and position in this witness list are not uninteresting. At the head of the list we find the šangûm and our group. Several other witnesses, not belonging to our group, are mentioned with a title or a patronymic, and in that respect Pala-Sin is an exception. His position as a male between the female witnesses at the end of the list is exceptional as well. We can only note his propinquity to temple officials. On the case (VS 8, 5), the witness list is not preserved.

39 Blocher (1992) assumed that the latter two were two different seals, but his drawings of both can be combined in a single one without any problem. Collation shows them to be the same indeed (Tanret 2010, 90). 

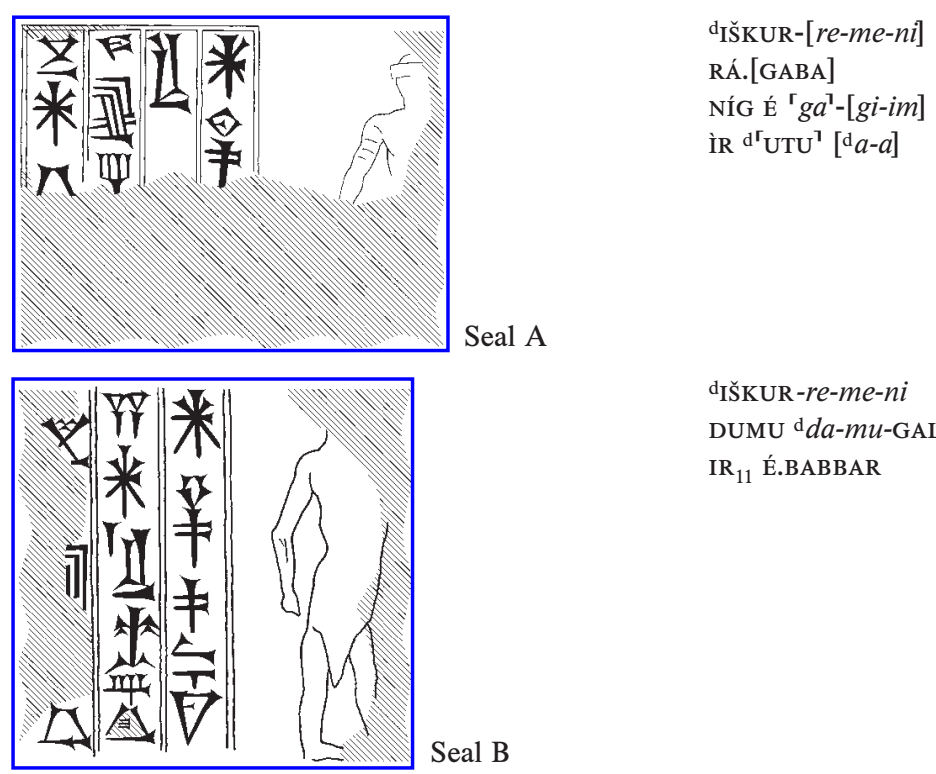

Seal A

$$
\begin{aligned}
& \text { dIŠKUR-[re-me-ni] } \\
& \text { RÁ.[GABA] } \\
& \text { NÍG É ' ' } g a^{\top} \text { - }[g i-i m] \\
& \text { İR d'UTU' }\left[{ }^{\mathrm{d}} a-a\right]
\end{aligned}
$$

\author{
${ }^{\mathrm{d}} \mathrm{IŠKUR}-r e-m e-n i$ \\ DUMU d $d a-m u-G A L-Z U$ \\ $\mathrm{IR}_{11}$ É.BABBAR
}

Seal B

Adad-rēmēni's change of title was not linked to the use of seals A and B, because seal B is already used under Sabium, while Adad-rēmēni still is chariot driver under the next king Apil-Sîn (MHET 66). Because there is no title mentioned on seal B, there is no conflict between the new seal and the old title. Because seal B is used until Sm it is practically certain that he did not have another one.

Adad-rēmēni's son Kalūmum may have inherited his father's title of doorkeeper. His earliest dated attestation is MHET 113 (Sm 6) where he appears amidst doorkeepers of the gagûm. We have one seal of him, again with no mention of a title (Teissier 1998 no 36, also used by his son Eidimana-mansum).

\title{
Idadum
}

Attestations: $\quad 21(\mathrm{Sle}-\mathrm{Sm})$, six in the present corpus.

Title: Doorkeeper (İ.DU $)_{8}$; attested on his seals (attested from AS on) and in texts from Sle on (MHET 18, CT 6, 26a).

Predecessor/father: Pala-Sîn (according to Idadum's seal; we have no certain other attestations of the father).

Successor/son: Unknown.

Seal:

Seal A with a three-lines legend (= Blocher 1992 no 280), found three times, all dated AS. ${ }^{40}$ Seal B with a four-lines legend (= Blocher 1992 no 262), found twice, dated AS and Sm. ${ }^{41}$ Both thus only appear on documents outside our chronological scope.

40 To be found on CT 48, 59, CT 45, 10 and MHET 66 (all AS).

41 To be found on CT 8, 29a (AS) and CT 47, 11 (Sm.) 


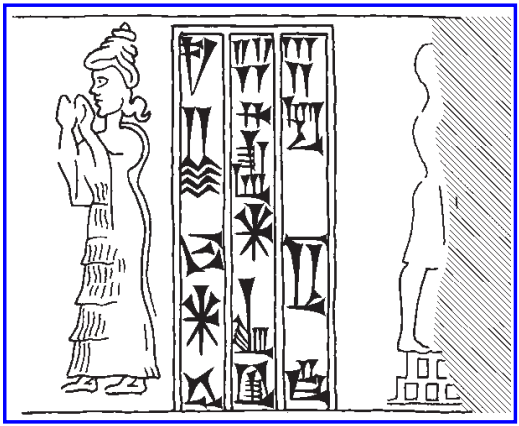

\author{
$i-d a-d u-u m$ \\ DUMU pa-la-d EN.ZU \\ ì.DU $\mathrm{NÍG}^{\mathrm{d}} \mathrm{UTU}$
}

Seal A

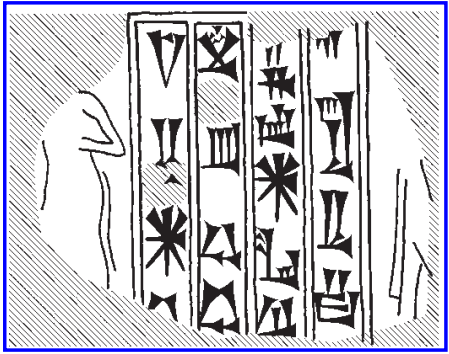

$i-d a-d u-u m$

DUMU pa-la-dEN.ZU

$\mathrm{IR}_{11}$ É.BABBÁR

İ.DU ${ }_{8}{ }^{\mathrm{d}} \mathrm{UTU}$

Seal B

Šamaš-liț̣ul

Attestations:

Title:

Predecessor/father:

Successor/son:

Seal:

$3(\mathrm{Sle}-\mathrm{Sa})$, all in the present corpus.

No title attested; could be a doorkeeper (cf. infra).

Unknown.

Šamaš-tappê, doorkeeper.

Unknown.

He is the father of a Šamaš-tappê who is a doorkeeper of the gagûmprecinct under Sm. ${ }^{42}$ Šamaš-tappê is consistently mentioned last of the temple officials, like his father. We have his seal, rolled on MHET 113 and on CT 4, 49b/MHET 121 (both Sm), with the legend:

dUTU-TAB.BA- $e$

DUMU dUTU- $l i-t h{ }^{\mathrm{r}} u l^{\top}$

'İ̀ É.BABBÁR'

Since Šamaš-littul's son was a doorkeeper and both men occupied the same place in the witness list, we suppose that father and son held the same title.

42 CT 47, 10; Ballerini, RSO 2, no 4 (Como 22); MHET 113 (with his seal); MHET 647; CT 4, 49b/MHET 121 (ì.DU ${ }_{8}$ KÁ ga-gi-im and his seal); BDHP 34/35 (ša KÁ ga-gi-im) and MHET 87 ( $\check{s} a$ KÁ ga-gi-im). All texts are to be dated under Sm. 
The fourth stage (Sabium and Lipit-Ištar)

Defining the stage

The criteria delimiting the fourth stage are a year name or an oath by Sabium, combined with the presence of the šangûm Lipit-Ištar (LI in the table below). The presence of the overseer Būr-Nunu allows us to separate this stage from the fifth in which he is replaced by his son Ilabrat-bāni. These criteria allow us to select five documents within our corpus.

\begin{tabular}{|c|c|c|c|c|c|c|c|c|c|}
\hline $\begin{array}{l}\text { CT } 6,40 \mathrm{c} / \\
\text { BM } 82513\end{array}$ & $\begin{array}{l}\text { Sa } \\
\text { year } \\
2\end{array}$ & $\begin{array}{l}1 / ?) \\
\mathrm{LI}\end{array}$ & & & $\begin{array}{l}\text { 2/?) Adad- } \\
\text { rēmēni + } \\
\text { seal A } \\
\text { CD }\end{array}$ & & & & \\
\hline VS 8,12 / 13 & $\begin{array}{l}\text { Sa } \\
\text { oath }\end{array}$ & $\begin{array}{l}1 / 1) \\
\text { LI }\end{array}$ & $\begin{array}{l}\text { 2/2) Būr- } \\
\text { nunu } \\
\mathbf{O}\end{array}$ & & $\begin{array}{l}\text { 4/3) Adad- } \\
\text { rēmēni + } \\
\text { seal B } \\
\text { CD }\end{array}$ & $\begin{array}{l}5 / 5^{43} \text { ) } \\
\text { Bulālum } \\
\text { D } \\
\text { BEGIN }\end{array}$ & $\begin{array}{l}6 / ?) \\
\text { Warad- } \\
\text { Šamaš } \\
\text { BEGIN }\end{array}$ & $\begin{array}{l}\text { 7/?) } \\
\text { Idadum } \\
\text { D }\end{array}$ & \\
\hline CT 48,27 & $\begin{array}{l}\mathrm{Sa} \\
\text { oath }\end{array}$ & $\begin{array}{l}1 / 1) \\
\text { LI }\end{array}$ & & & $\begin{array}{l}\text { 2/2) Adad- } \\
\text { rēmēni } \\
\text { CD }\end{array}$ & $\begin{array}{l}\text { 3/3) } \\
\text { Bulālum } \\
\text { + seal A } \\
\text { D }\end{array}$ & $\begin{array}{l}4 / 4) \\
\text { Warad- } \\
\text { Šamaš }\end{array}$ & & \\
\hline MHET 28 & $\begin{array}{l}\mathrm{Sa} \\
\text { oath }\end{array}$ & $\begin{array}{l}\text { 1) } \\
\text { LI }\end{array}$ & 2) Būr-nunu & $\begin{array}{l}\text { 3) } \\
\text { Amurrum- } \\
\text { bāni D }\end{array}$ & $\begin{array}{l}\text { 4) Adad- } \\
\text { rēmēni } \\
\text { CD }\end{array}$ & & & \begin{tabular}{|l|}
$5)$ \\
Šamaš-lițtul
\end{tabular} & \\
\hline CT 47,1 & $\begin{array}{l}\text { Sa } \\
\text { oath }\end{array}$ & $\begin{array}{l}\text { 1) } \\
\text { LI }\end{array}$ & $\begin{array}{l}\text { 2) Būr-nunu } \\
\text { END }\end{array}$ & $\begin{array}{l}\text { 3) } \\
\text { Amurrum- } \\
\text { bāni D } \\
\text { END }\end{array}$ & $\begin{array}{l}\text { 4) Adad- } \\
\text { rēmēni } \\
\text { CD }\end{array}$ & & & \begin{tabular}{|l|} 
5) \\
Šamaš-lițul \\
END
\end{tabular} & $\begin{array}{l}\text { 6) Ilabrat- } \\
\text { bāni } \\
\text { (BEGIN?) }\end{array}$ \\
\hline
\end{tabular}

The order of the texts

Apart from the following observations, the order of the texts within our stage four is arbitrary.

At first sight CT 6, 40c/BM 82513, which has the year name ' $\mathrm{mu}$ ú s. $\langle$ sa〉sà-bi-um lugal.e', the second year of Sabium (Horsnell 1999, 66), could be placed anywhere within this stage or the next (but before CT 6 , 47a/MHET 44, dated Sabium year 10) since, apart from the šangûm, the only other member of the group mentioned in it is Adad-rēmēni. His presence and more precisely his seal use allow us to place the text at the beginning of stage four. Indeed, on CT $6,40 \mathrm{c} / \mathrm{BM} 82513$, he uses his earlier seal "A" (cf. supra) while on VS 8, 12/13 he uses his later one, "B", which places our text firmly in stage four and gives us the order of these two texts.

43 On the case there is a completely broken name before Bulālum. 
On CT 47, 1 the last witness of the group is Ilabrat-bāni, son of BūrNunu, who will take over his father's title and place in the next stage. That is why we have placed this text at the end of stage four.

CT 48, 27 could be placed anywhere during Sabium's reign but some argument can be made to place it in stage four. The members of the group in its witness list are the same as in CT 6,19a, except for the presence of Ilabrat-bāni which places the latter text in stage five. Another difference is that Bulālum still uses his seal A on CT 48, 27. This is the reason why we have placed it in stage four.

MHET 28 could be placed anywhere within this stage.

First and last attestations

In this stage we find the first attestation of Būr-Nunu's son and successor Ilabrat-bāni in CT 47, 1, a text in which both father and son are witness, which is exceptional. Bulālum, a doorkeeper, appears for the first time in this stage, as well as the courtyard-sweeper (KISAL.LUH) WaradŠamaš, who will always follow immediately after Bulallum when both are present. Amurrum-bāni, who had started in our second stage, ends in stage four. Šamaš-litțul, who started in stage three, also ends here.

\section{The sequence within the group}

Taking over his father's title, Ilabrat-bāni starts his career as overseer of the naditum-priestesses. In his first attestation his father Būr-Nunu is still overseer and second witness whereas Ilabrat-bāni is the last of the group. Such a low place would befit a newcomer, as we have seen. This is repeated on the first text of the fifth stage where, although Būr-Nunu has disappeared, Ilabrat-bāni still comes after the chariot driver Adad-rēmēni. It is only after this that Ilabrat-bāni takes his place as second witness.

After the šangûm, the overseer, the doorkeeper Amurrum-bāni and the chariot driver Adad-rēmenni there seem to be three slots. The first one is occupied by Bulālum, doorkeeper; the second by Warad-Šamaš, courtyard-sweeper and the third one by either Idadum, doorkeeper, or Šamašlittul, probably with the same title.

All of them are newcomers; none are descendants of temple personnel. They now constitute the lowest part of the group.

The appearance of Idadum as last witness, however, must be a carelessness of the scribe. He actually belongs before Bulālum and Warad-Šamaš. First, in CT 2, 3 (stage six) he appears before Bulālum and Warad-Šamaš (and even before Adad-rēmēni). Second, it is on the tablet of VS 8, 12/13, that Idadum is last witness. We frequently find a different order of wit- 
nesses between tablet and case, with the case generally giving the more accurate list ${ }^{44}$. His place before Adad-rēmēni in CT 2, 3 must be a similar error and is discussed in stage six.

\section{Who are these people?}

\section{Bulālum}

Attestations:

20 (9 Sa, $11 \mathrm{Sm}), 9$ times in the present corpus ${ }^{45}$.

Title: Doorkeeper (ì.DU ${ }_{8}$; never in the text, only on his seal A).

Predecessor/father: Akum, otherwise unknown.

Successor/son: Unknown.

Seal:

Seal A with a four-line legend (= Blocher 1992 no 164) attested once under $\mathrm{Sa}^{46}$. Seal B with a three-line legend (= Blocher 1992 no 112) attested on seven envelopes dated $\mathrm{Sa}$ and $\mathrm{Sm} .{ }^{47}$

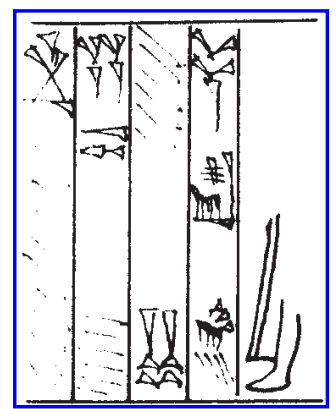

$$
\begin{aligned}
& \text { bu-la-lum } \\
& \text { [ì].DU } 8 \\
& \text { DUMU } a \text {-[ }[k i-i m] \\
& \text { İR [É.BABBÁR] }
\end{aligned}
$$

Seal A

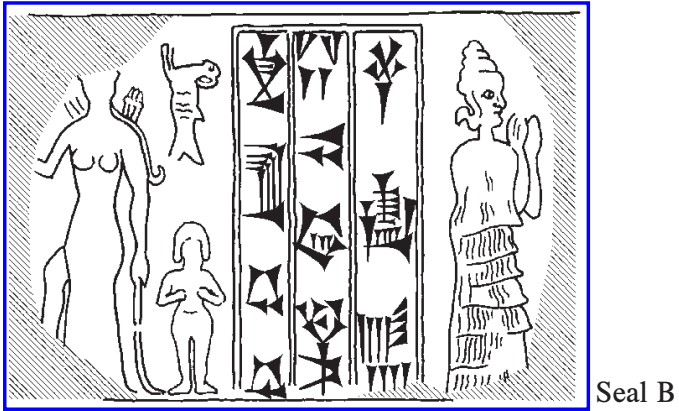

bu-la-lum DUMU a-ki-im Ìr É.BABBÁR

${ }_{44}$ The case is generally written more elaborately (dEN.ZU instead of Sin on the tablet), sometimes patronymics are added which are not to be found on the tablet, sometimes even formulas are omitted on the tablet and this is of course all related to the fact that the Old Babylonians never expected to see the tablet again, enclosed as it was and only to be shown in case of a litigation, when the judges would break the envelope.

45 BM 17249, a fragment which carries his seal B, was not counted here because his name is not preserved on the fragment.

$46 \mathrm{CT} 48,27(\mathrm{Sa})$.

47 MHET 44, MHET 45, BDHP 23 and BM 17249 (unpublished, cf. Blocher 1992, 56, XXXII) (all Sa); MHET 102, MHET 113, CT 47, 15a (all Sm). 


\section{Warad-Šamaš}

Attestations:

Title:

Predecessor/father:

Successor/son:

Seal:
Five (Sa-AS); four in the present corpus (stages 4, 5 and 6 all dated $\mathrm{Sa}^{48}$ ), one dated $\mathrm{AS}^{49}$.

Courtyard-sweeper (KISAL.LUH ${ }^{50}$ ) on his seal only.

Unknown.

Unknown.

Attested once on a document outside of our corpus ${ }^{51}$ (= Blocher 1992 no 281).

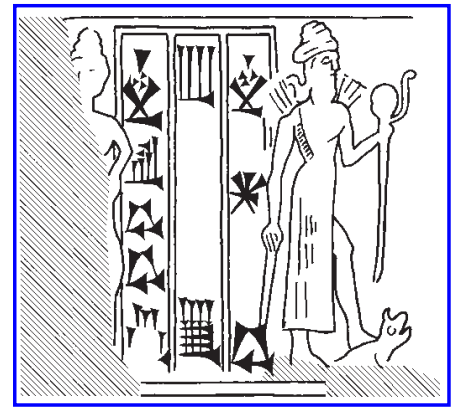

ÌR-dUTU

KISAL.LUH

İR É.BABBÁR.RA

\section{Ilabrat-bānī}

Attestations:

21 ( $\mathrm{Sa}-\mathrm{AS}), 9$ in the present corpus.

Title:

Oversee of the naditum-priestesses (UGULA LUKUR dUTU). His title is stated in six texts ${ }^{52}$ and on his seal $\mathrm{B}$.

Predecessor/father:

Successor/son:

Būr-nunu, overseer of the naditum-priestesses.

Seal:

Ninšubur-mansum (first attested under AS).

Seal A with a three-line legend (= Blocher 1992 no 115) attested on two Sa envelopes. ${ }^{53}$ His son uses this seal on one envelope dated AS 7.54 Seal B with a four-line legend (= Blocher 1992 no 126) attested on two Sa and four AS envelopes. ${ }^{55}$ It is further rolled on six Sm envelopes on which it is used by his son Ninšubur-mansum ${ }^{56}$ and one dated $\mathrm{Ha} 30^{57}$ where it is used by his grandson Būr-nunu.

CT 2, 3; CT 6, 19a; CT 48, 27; VS 8, 12/13.

CT 48, 59.

50 Cf. note 6.

51 CT 48, 59 (AS).

52 CT 2, 3 and CT 48, 14, both dated Sa 13; in CT 48, 29, CT 45, 10 (with title and patronymic), MHET 6, MHET 66 all dated AS.

53 MHET 44 (case of CT 6, 47a) dated Sa 10 and MHET 35 (case of CT 4, 26b) dated to Sa by the oath.

54 MHET 77. Date contra Dekiere 1994, who gives AS 6. Cf. Horsnell (1999, Vol. 2, 79-80).

55 MHET 45 (case of CT 2, 50) dated Sa 12 and CT 48, 14 dated Sa 13; CT 45, 10, CT 47, 7a, CT 48, 29 and MHET 66 (all AS).

56 CT 4, 49b (dated Sm 4), CT 47, 11a, CT 47, 12a, MHET 107, MHET 109 and TCL 1, 69.

57 MHET 238 (Ha 30). 


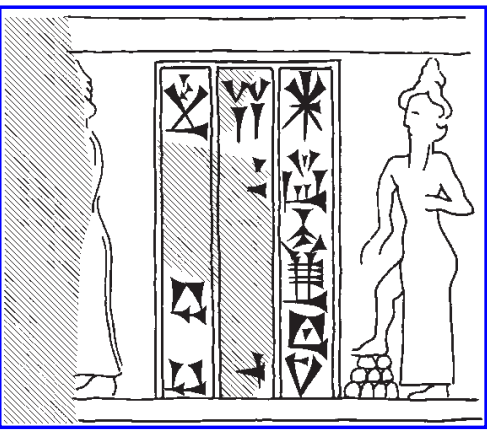

$\mathrm{d}_{\mathrm{NIN} . S ̌ U B U R}-b a-n i$ DUMU bur-nu-nu ÌR É.BABBÁR

Seal A

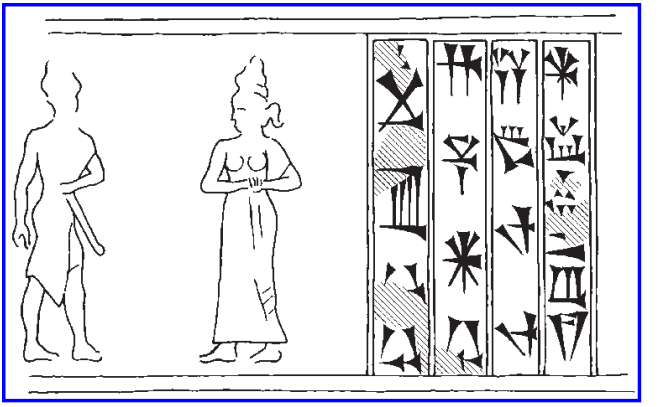

${ }^{\mathrm{d} N I N . S ̌ U B U R}-b a-n i$ DUMU bur-nu-nu UGULA LUKUR dUTU Ìr É.BABBÁR

A small excursus on the use by the son of his father's two seals

This is a rare occasion on which we can observe a son using both seals of his father. Ilabrat-bāni's use of his seal A is attested until Sa 10 and his use of his seal B is attested in Sa 13, 14 (the last year of this king) and four times under AS. His son Ninšubur-mansum uses seal A in AS 7 and his use of seal B is attested from $\mathrm{Sm} 4$ on.

The most probable scenario is the following: The son's use of his father's seal A in AS 7 could roughly coincide with his taking over his father's office. The odd thing is that later he switches to his father's seal B, certainly from Sm 4 onwards (15 years later). Why would the son not simply start using his father's second seal? We can only suggest that his father continued to use his more recent seal B for the remainder of his life, and that it was only after his death (somewhere before $\mathrm{Sm} \mathrm{4}$ ) that his son inherited that seal and began using it. ${ }^{58}$ This begs the question what the

58 On this basis we can calculate his approximate term of office and life span. Ilabrat-bāni's father and predecessor Būr-Nunu is still attested under Sabium. Under this same king, probably in the earlier part of the reign, Ilabrat-bāni takes over. He would have had a career of about 18 years (counting from Sa 2 to AS 6 after which his son starts using his seal A). If we suppose that he passed away in Sm 3 at the latest and started his career at 20 (and was thus born in Sle 18) he would have lived 53 years. 
father would be using his seal B for when he was no longer in office. Since we do not yet have traces of economic or any other activity of these temple officials (cf. supra), this remains an open question for the time being.

Sealing pattern of stages 3 and 4

Coinciding with Lipit-Ištar's first attestation the sealing pattern changes. The šangûm still seals the upper edge, but from now on the second witness seals the lower edge, and any further temple officials seal the left edge. This practice first occurs on CT 8, 44a/CT 48, 31 (Sle), and is found until CT 48, 27 ( $\mathrm{Sa}$, at the end of stage four). We summarize this new sealing pattern ${ }^{59}$ :

\begin{tabular}{|l|l|l|l|}
\hline Text & $\begin{array}{l}\text { First witness, } \\
\text { always on UE }\end{array}$ & $\begin{array}{l}\text { Second witness } \\
\text { always on LoE }\end{array}$ & $\begin{array}{l}\text { Other witnesses } \\
\text { always on LE }\end{array}$ \\
\hline CT 8, 44a/CT 48, 31 & Lipit-Ǐstar, šangûm & Būr-nunu & Amurrum-bāni, ì.DU \\
\hline CT 6, 26a/BM 17105 & [Lipit-Ištar] & [Būr-nunu] & \\
\hline MHET 18 & [Lipit-Ištar] & Būr-nunu & Amurrum-bāni (?) \\
\hline CT 6, 40c/BM 82513 & Lipit-Ištar & Adad-rēmēni & \\
\hline VS 8, 12/13 & [Lipit-Ištar] & Būr-nunu & Adad-rēmēni \\
\hline CT 48,27 & Lipit-Ištar & [Adad-rēmēni] & Bulālum, İ.DU $_{8}$ \\
\hline
\end{tabular}

The sequences UE - LoE - LE is confirmed by the fact that when BūrNunu, the 'normal' occupant of the LoE as second witness, is absent, Adad-rēmēni who would 'normally' seal on the LE moves to the LoE.

The fifth stage (Lipit-Ištar and Ilabrat-bāni)

Defining the stage

This stage can be distinguished from the preceding one by the presence of Ilabrat-bāni, son of Būr-Nunu and successor of his father as overseer. It can be distinguished from the next stage by the fact that there the role of second šangûm will appear for the first time. These criteria allow us to select five documents from our corpus, all of which can be dated to the reign of Sabium. Lipit-Ištar (LI in the table below), first šangûm, is attested in only one text.

$59 \mathrm{UE}=$ upper edge; $\mathrm{LE}=$ left edge $; \mathrm{LoE}=$ lower edge; Rev $=$ reverse. Straight brackets indicate that the seal must have been rolled on the now lost edge of the case. 
The order of the texts

We consider CT 4, 26b to be the first text, since here Ilabrat-bāni still has a lower position, just like in the last text of the preceding stage. In the four other texts of stage five he takes his father's place at the head of the group or immediately after the šangûm.

Three of these other texts are dated in Sa 10 (it u ti-ru-um ud.8.kam $\mathrm{mu}$ é.sag.íla sà-bi-um ba.dù), 11 (itu ti-ru-um mu alam sà-bi-um ba.dím.ma) and 12 (itu ezen diškur mu bàd ka-zal-1uki). The fourth (CT 6, 19a), however, is datable only by the oath and could be placed anywhere in this stage. There are no new officials appearing in this stage and none end their career during it.

\begin{tabular}{|l|l|l|l|l|l|l|l|}
\hline $\begin{array}{l}\text { CT 4, 26b/ } \\
\text { MHET 35 }\end{array}$ & $\begin{array}{l}\text { Sa } \\
\text { oath }\end{array}$ & & $\begin{array}{l}\text { 5/6) Adad- } \\
\text { rēmēni + } \\
\text { seal B CD }\end{array}$ & $\begin{array}{l}\text { 6/7) Ilabrat- } \\
\text { bāni } \\
\text { + seal A }\end{array}$ \\
\hline CT 6, 19a & $\begin{array}{l}\text { Sa } \\
\text { oath }\end{array}$ & 1) LI & $\begin{array}{l}\text { 2) Ilabrat- } \\
\text { bāni }\end{array}$ & $\begin{array}{l}\text { 3) Adad- } \\
\text { rēmēni } \\
\text { CD }\end{array}$ & 4) Bulālum & $\begin{array}{l}\text { 5) Warad- } \\
\text { Šamaš }\end{array}$ & \\
\hline $\begin{array}{l}\text { CT 6, 47a/ } \\
\text { MHET 44 }\end{array}$ & $\begin{array}{l}\text { Sa } \\
10 / 7 / 8\end{array}$ & & $\begin{array}{l}\text {-/4) Ilabrat- } \\
\text { bāni + } \\
\text { seal A }\end{array}$ & $\begin{array}{l}\text {-/5) Adad- } \\
\text { rēmēni } \\
\text { CD }\end{array}$ & $\begin{array}{l}\text { 8/6) Bulālum } \\
\text { + seal B } \\
\text { D }\end{array}$ & & \\
\hline BDHP 22/23 & $\begin{array}{l}\text { Sa } \\
11 / 7 /-\end{array}$ & & $\begin{array}{l}\text {-/4) Bulālum } \\
\text { + seal B D }\end{array}$ & & \\
\hline $\begin{array}{l}\text { CT 2, 50/ } \\
\text { MHET 45 }\end{array}$ & $\begin{array}{l}\text { Sa } \\
12 / 11 /-\end{array}$ & $\begin{array}{l}\text { 7/6) Ilabrat- } \\
\text { bāni + } \\
\text { seal B }\end{array}$ & $\begin{array}{l}\text { 8/7) Adad- } \\
\text { rēmēni } \\
\text { CD }\end{array}$ & $\begin{array}{l}\text { 1060/7) Bulālum } \\
\text { + seal B D }\end{array}$ & & \\
\hline
\end{tabular}

The sequence within the group

Apart from the first text in which the novice overseer Ilabrat-bāni witnesses after the chariot driver Adad-rēmenni, the order is always the same in this stage: šangûm (present only once), overseer, chariot driver, doorkeeper and courtyard sweeper.

The sealing order

There are four sealed documents in this group that show that in the sealing- and witness order judges apparently ranked higher than temple officials, and Babylonian judges ranked higher than Sipparean ones, as we will now explain.

${ }^{60}$ Ninth witness on the tablet and on the case is an otherwise unknown Ilšu-bāni. 
MHET 35 (case of CT 4, 26b) has on its left edge (top to bottom) the seal impressions of Adad-rēmēni and Ilabrat-bāni (rolled twice). This perfectly reflects the order in the witness list. The upper edge has a seal without a legend which is repeated on the lower edge. The second and third witness, Išme-Adad son of Elali-waqar, and Nūr-ilišu son of Būr-Sîn are known to be judges, ${ }^{61}$ which means the first witness, Bamatum son of Iluma might be one too. Išme-Adad seals on the right edge and on the reverse. ${ }^{62}$ This means that the first witness/judge, Bamatum, may be the owner of the seal without legend on the upper and lower edges. The upper and lower edge are thus sealed by a judge, the left edge by temple officials.

MHET 44 (case of CT 6, 47a) bears seals of the judges from Babylon on its upper and left edges. On the lower edge, one Babylonian judge and one Sipparean judge seal. The Sipparean is Ilabrat-bāni, acting as a judge. Bulālum ist also mentioned among the judges but seals at the bottom of the right edge. There is no trace of Adad-rēmēni's seal. There seems to be a general concordance with the witness list: the upper and lower edges are sealed by judges from Babylon and a high ranking local judge. The left edge is sealed by other Babylon judges, the right edge by a Sipparean temple official.

On BDHP 23 (case of BDHP 22), the first witness seals on the top left edge and Bulālum, the only temple official, seals the upper edge. In view of the fact that this is a juridical document, the first witness might be a judge, although this is not spelled out in the text. ${ }^{63}$ The top of the left edge thus seems to be the most important place, the upper edge is now occupied by Bulālum, a rather lowly temple official, who is not mentioned on the tablet and is only fourth witness on the case. The bottom of the left and lower edges and the top of the reverse have unidentified seals without legends.

On MHET 45 (case of CT 2, 50), the upper and lower edges are sealed by judges who are the first and second witnesses (Ibbi-Sîn son of Nabiilišsu and Išme-Adad son of Elali-waqar $\left.{ }^{64}\right)$; the left edge is sealed by temple officials. Bulālum seals second on the left edge and Ilabrat-bāni third, although on the case they are witness 4 and 2 respectively. There is no trace of Adad-rēmēni's seal, although he is witness 3 on the case. The inversion of Bulālum and Ilabrat-bāni could be explained by the fact that these seals

${ }_{61}$ Based on comparison with MHET 17/CT 8, 28a and CT 2, 50/MHET 45.

62 The uninscribed seal found there is attributed to him based on comparison with MHET 17/CT 8, 28a and CT 2, 50/MHET 45.

${ }^{63}$ Hillum, judge from Babylon is mentioned, just as in MHET 44, alongside an unnamed judge from Sippar and an equally unnamed one of the gagûm precinct.

64 The latter seal is attributed by comparison with MHET 17/CT 8, 28a and CT 4, 26b/MHET 35. 
are rolled upside down on the left edge, meaning that the tablet was held upside down, in which case the order reflects that of the witness list.

With due prudence we can see a pattern in this. Judges (appearing before the witnesses) seal the upper and lower edge; temple officials follow on the left and right edges of three of our four texts. BDHP 23 ist an exception. Here, Bulālum is the only witness of our group and he exceptionally seals on the upper edge.

The sixth and seventh stages (Išar-Šamaš/Sîn-ennam)

\section{Defining the stages}

Since the seventh stage only contains one text, we will discuss it together with stage six. The sixth stage is distinguished from the fifth by the appearance of Išar-Šamaš, who is the first person to be second šangûm of Šamaš. As could be expected, he will always be second witness in the group. On the basis of these criteria there are three texts in stage six. IšarŠamaš' successor, Sîn-ennam, appears in only one text (MHET 567), ${ }^{65}$ which alone makes up stage seven.

The order of the texts

The only dated document that attests Išar-Šamaš is CT 2, 3 and was written in the 13th and penultimate year of Sabium. Within stage six no criterion can be found to classify the three texts chronologically.

\begin{tabular}{|c|c|c|c|c|c|c|c|c|}
\hline $\begin{array}{l}\text { MHET } \\
30\end{array}$ & Sa oath & 1) $\mathrm{LI}$ & $\begin{array}{l}\text { 2) Išar- } \\
\text { Šamaš66 }\end{array}$ & $\begin{array}{l}\text { 3) Ilabrat-bāni } \\
\text { o }\end{array}$ & & $\begin{array}{l}\text { 4) Adad- } \\
\text { rēmēni } \\
\text { CD }\end{array}$ & $\begin{array}{l}\text { 5) Bulālum } \\
\text { D }\end{array}$ & \\
\hline BDHP 68 & Sa oath & 1) $\mathrm{LI}$ & $\begin{array}{l}\text { 2) Išar- } \\
\text { Šamaš }\end{array}$ & $\begin{array}{l}\text { 3) Ilabrat-bāni } \\
\text { O }\end{array}$ & & & & \\
\hline CT 2,3 & Sa 13/7/-67 & 1) $\mathrm{LI}$ & $\begin{array}{l}\text { 2) Išar- } \\
\text { Šamaš }\end{array}$ & $\begin{array}{l}\text { 3) Ilabrat-bāni } \\
\text { o }\end{array}$ & $\begin{array}{l}\text { 4) Idadum } \\
\text { D }\end{array}$ & $\begin{array}{l}\text { 5) Adad- } \\
\text { rēmēni } \\
\text { CD }\end{array}$ & $\begin{array}{l}\text { 6) Bulālum } \\
\text { D }\end{array}$ & $\begin{array}{l}\text { 7) Warad- } \\
\text { Šamaš }\end{array}$ \\
\hline $\begin{array}{l}\text { MHET } \\
567\end{array}$ & {$\left[\begin{array}{lll} \pm & \mathrm{Sa} & 14\end{array}\right]$} & 1) $\mathrm{LI}$ & $\begin{array}{l}\text { 2) Sîn- } \\
\text { ennam }\end{array}$ & $\begin{array}{l}\text { 3) Ilabrat-bāni } \\
\text { o }\end{array}$ & & $\begin{array}{l}\text { 4) Adad- } \\
\text { rēmēni } \\
\text { CD }\end{array}$ & $\begin{array}{l}\text { 5) Bulālum } \\
\text { D }\end{array}$ & \\
\hline
\end{tabular}

\footnotetext{
65 The identity of Sîn-ennam as second šangûm, successor of Išar-Šamaš and predecessor of Šumuh-Sîn is discussed by Tanret $(2010,94)$.

66 Contra Dekiere; collation M. Tanret.

67 itu ti-ru-um mu e a.ab.ba-hé.gál.
} 
First and last attestations

Išar-Šamaš must have become second šangûm in Sa 13 (cf. supra). His successor Sîn-ennam (stage seven) is in his turn succeeded by second šangûm Šumuh-Sîn, who is attested in Apil-Sîn's first year68, one year after our dated attestation of Išar-Šamaš. This means that Sin-ennam must be situated around the last year of Sabium, i.e. Sa 14. His tenure must have lasted about a year.

All the other officials appearing in these two stages were already attested previously, and all officials are still found in later texts.

The sequence within the group

From now on, not only within our present group of texts but throughout the period of attestation of the phenomenon we are describing, there are three slots at the top of the group: first šangûm - second šangûm overseer of the naditum priestesses. These are followed by three other slots that are occupied by a chariot driver, a doorkeeper and, when present, a courtyard sweeper. After the period under consideration here, the last three slots will be occupied by doorkeepers only.

The doorkeeper Idadum, who was not attested in stage five, reappears in stage six on CT 2, 3. Here, he jumps ahead of Adad-rēmēni. This document is a tablet whose case is now lost and we suppose that on the case he would have occupied his expected place, after Adad-rēmēni. ${ }^{69}$

Who are these people?

The second šangûms Išar-Šamaš and Sîn-ennam are discussed in detail elsewhere. ${ }^{70}$

There are no sealed documents preserved in these two stages.

68 CT 8, 29b.

69 For instance, CT 45, 10 (AS) (relating to the same plot of land that is sold in CT 2,3) has preserved its case. On the tablet we have the sequence first šangûm - second šangûmAdad-rēmēni - Idadum .... On the case we have: first šangûm - second šangûm - Ilabrat-bāni (rest broken). This shows that on the tablet even the overseer Ilabrat-bāni could be left out.

70 Tanret (2010, 93-95). 


\section{Conclusion}

The schematic rendering on the next page shows the development of our group of officials through time. Apart from the top row, with the kings to which our texts are dated, the diagram shows five to twelve bands, representing from top to bottom the order of witnesses in the witness list. The trajectory of each individual across the bands, as time progresses, is represented by a shaded area in which the individual's name is repeated several times. The shades of grey applied to these areas are added to better distinguish the different individuals' trajectories. When an individual is attested for the first time, and his career/shaded area begins, this is indicated by a thick black line. Likewise, his last attestation is indicated by a double line. Only where a person is immediately followed by his successor in the same band have we omitted the end markers, again for visual clarity.

Only Idadum fails to be attested continuously throughout the stages where he must have been in office. He is found in stages three, four and six, and is still in office after stage seven, but is not attested at all during stages five and seven. Since he belongs after Adad-rēmēni and before Bulālum (stages four and six, supra), this is where he is placed in the overview.

Because the diagram aims to illustrate a general pattern, and yet again for visual clarity, we have not indicated the occasional absence of officials from the witness lists as interruptions in their shaded area.

\section{Successions}

Amurrum-bāni did not follow into his father Ilum-mušallim's position immediately, but only gradually moved up in the order of witnesses, until in stage three he reached his father's place behind the overseer. This we have explained above as seniority taking precedence over title. Another instance is Ilabrat-bāni appearing at the bottom of the list in stage four, to take up his father's place only in stage five.

In two cases successors immediately take over their father's ranking. This happens when Būr-nunu succeeds his father Imlik-Sîn in stage one, but here the son's title is different from his father's. The other case is to be found in stage three, where Adad-rēmēni takes over from his father Damu-galzu immediately and with the same ranking. We cannot at present explain why he does not start lower in the list.

Even in the sequence of successions in the functions of first and second šangûm we can witness instances of seniority outranking title. Twice, outside our present chronological scope, a new first šangûm briefly takes the position of second witness after the senior second šangûm who briefly takes the first position. 


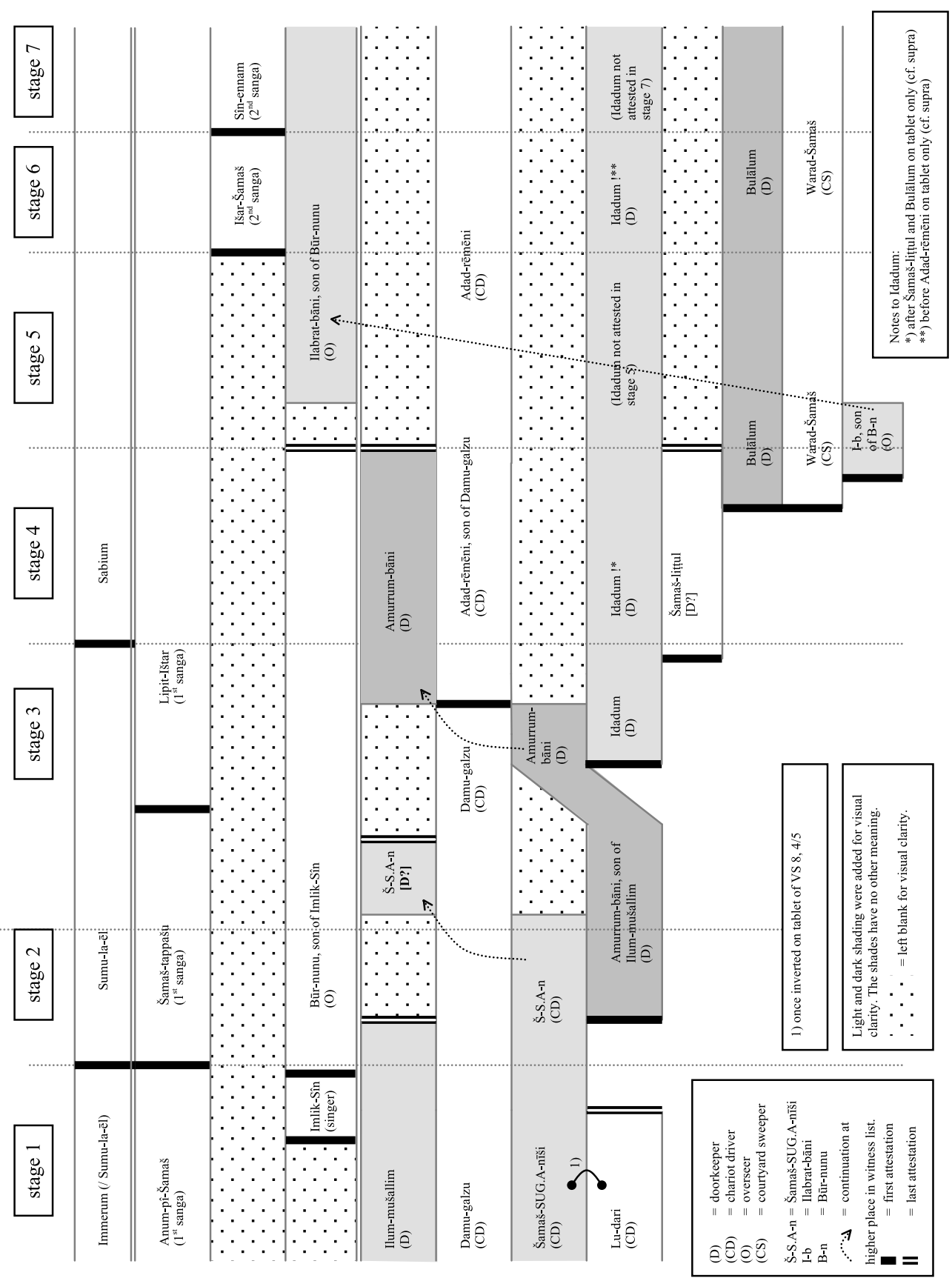


Tablet and case

The case of a document, including the witness list, was generally drawn up more carefully and accurately than the tablet. This allowed us in stage four to place Idadum before Bulālum and Warad-Šamaš and in stage six immediately after Adad-rēmēni, where he must belong.

Hereditary offices?

We have a few instances of a father-to-son succession. The only title which stayed in the hands of one and the same family throughout the whole Old Babylonian period was that of first šangûm of Šamaš. ${ }^{71}$ The next best seems to have been the title of overseer of the naditum priestesses, which was held by the descendants of Imlik-Sîn at least until the last years of Hammu-rabi. All the other titles, even the second šangûms, seem to be held within a family for a few generations only, being transmitted from father to son, after which they pass to another family. We must be cautious, however. Apart from those of the sangûms and the overseers, we know nearly nothing about these families. It is possible that when the consecutive holders of these titles were not father and son they were nevertheless related, for example as cousins. In the absence of knowledge about their wider family composition this escapes us completely. In the family of the overseer, whose family tree we have, ${ }^{72}$ the succession is mostly from father to son (and daughter in some cases), with one exception, when a cousin takes over: the third overseer is Ninšubur-mansum (cf. supra) son of Ilabrat-bāni and the fourth one is Ninšubur-mansum's cousin Sîn-bāni, son of Šamaš-ilum, the brother of Ilabrat-bāni. ${ }^{73}$ If we had not had the family tree, we would too easily have classified them as members of different families.

With due caution we conclude that, as far as we know, some families seem to hold their office during a few generations only. Ilum-mušallim is succeeded by his son Amurrum-bāni, but we could not find any further direct descendant of them among the temple officials. Damu-galzu's son Adad-rēmēni is succeeded by his son Kalūmum, outside our corpus. Kalūmum, in his turn, is succeeded by his son Eidimanna-mansum around the beginning of Hammu-rabi's reign, after which we cannot trace the family any further. For Šamaš-litțul and his son Šamaš-tappê we could only assume that the office went from father to son (cf. supra).

\footnotetext{
71 Tanret (2010).

72 Tanret $(2010,85)$.

73 Tanret $(2010,85)$.
} 
In general we can conclude that there was a clear tendency (or even ambition?) to keep a title within a family. Either this was successfully achieved, but escapes our observation because in most cases we have no overview of the larger family, or there was some competition for these titles, as a result of wich they were 'conquered' by different families successively. For the second šangûms it has been observed that the competitive model was the most likely. ${ }^{74}$

\section{The seals}

In all we have thirteen seals belonging to nine temple officials out of twelve, not counting the first and second šangûm whose seals have been studied elsewhere..$^{75}$ Five officials have one and four have two seals. A general overview of the seal ownership and the seal legends is given below.

Title: O(verseer of the nadiātum), D(oorkeeper), C(ourtyard) S(weeper), C(hariot) D(river)

The columns "Seal 1" and "2" give the dates and frequency of seal impressions

The columns "Legend" give for each line of the legend: N(ame), P(atronymic), T(itle), S(ervant line: Ì̀ ....).

The columns "Career" gives the kings under whose reign the official is attested.

'd.': DUMU

\begin{tabular}{|c|c|c|c|c|c|c|}
\hline Official & Title & Seal 1 & Legend & Seal 2 & Legend & Career \\
\hline Būr-nunu & 0 & Sle $(6 \times)$ & NTPS & - & - & $\mathrm{Im}-\mathrm{Sa}$ \\
\hline Ilum-mušallim & $\mathrm{D}$ & $\operatorname{Im}-\operatorname{Sle}(3 / 4 \times)$ & NTT & - & - & $\begin{array}{l}\mathrm{Im}-\mathrm{Sle} / \\
\mathrm{Bti}\end{array}$ \\
\hline Damu-galzu & $\mathrm{CS} \rightarrow \mathrm{CD}$ & s.d. $(1 \times)$ & NTTS & - & - & Im-Sle \\
\hline Šamaš-SUG.A-nišĩ & $\mathrm{CD}[\rightarrow \mathrm{D} ?]$ & - & - & - & - & Im-Sle \\
\hline Lū-dāri & $\mathrm{CD}$ & - & - & - & - & Im-Sle \\
\hline $\begin{array}{l}\text { Amurrum-bāni } \\
\text { d. Ilum-mušallim }\end{array}$ & D & Sle $(1 \times)$ & NPTT & - & - & Sle-Sa \\
\hline $\begin{array}{l}\text { Adad-rēmēni } \\
\text { d. Damu-galzu }\end{array}$ & $\mathrm{CD} \rightarrow \mathrm{D}^{76}$ & $\mathrm{Sa}(1 \times)$ & NTTS & $\mathrm{Sa}-\mathrm{Sm}(5 \times)$ & NPS & Sle-Sm \\
\hline Idadum & D & $\operatorname{AS}(3 \times)$ & NPT & $\operatorname{AS}-\operatorname{Sm}(2 \times)$ & NPST & Sle-Sm \\
\hline Šamaš-lițtul & [D?] & - & - & - & - & Sle-Sa \\
\hline Bulālum & D & $\mathrm{Sa}(1 \times)$ & NTPS & $\mathrm{Sa}-\mathrm{Sm}(7 \times)$ & NPS & $\mathrm{Sa}-\mathrm{Sm}$ \\
\hline Warad-Šamaš & CS & $\operatorname{AS}(1 \times)$ & NTS & - & - & $\mathrm{Sa}-\mathrm{AS}$ \\
\hline $\begin{array}{l}\text { Ilabrat-bāni } \\
\text { d. Būr-nunu }\end{array}$ & $O$ & $\mathrm{Sa}-\mathrm{AS}(3 \times)$ & NPS & $\begin{array}{l}\text { Sa-AS-Sm-Ha } \\
(13 \times)\end{array}$ & NPTS & $\mathrm{Sa}-\mathrm{AS}$ \\
\hline
\end{tabular}

74 Tanret $(2010,203)$.

75 Tanret (2010).

76 This change occurs outside our corpus, cf. supra, stage 3. 
One or two seals?

The table seems to show that the earlier officials only owned one seal, while the later ones often had two. We should be careful however, because, as the saying goes, absence of evidence does not necessarily mean evidence of absence. The table shows that when an official used two seals this was always in succession, never at the same time. Why and when the seal was changed remains an open question and no easy answer is available. One could think that they first had a seal without a title, and subsequently their title was added on their second seal. This is not the case. Only once is a title added (by Ilabrat-bāni NPS > NPTS), but it is dropped twice (by Adad-rēmēni (NTTS $>$ NPS and Bulālum NTPS $>$ NPS) or it was already present on the first seal (Idadum NPT $>$ NPST).

Adad-rēmēni is a special case since his first seal's legend mentions his chariot driver (RÁ.GABA) title. He later had a new seal made, without the chariot driver title. The question remains why he did not indicate his new title on his new seal. We also note that he changed the dedication in the servant line from "Šamaš [and Aja?]" to "Ebabbar" between seals. Concerning the iconography, we note that both seals have a king with a mace with his back to the legend, this indicates some similarity in the choice of the seal scene. Further than that nothing can be said because the other figure(s) on the seal are lost.

Concerning Idadum's two seals little can be said. The only difference in the legends is the addition of "servant of the Ebabbar" as the penultimate line, which is very unusual because the servant line usually comes last. Such a change is hardly sufficient reason to have a second seal made. Too little is preserved of the seal scenes to allow any comments, apart from the observation that both have two figures with their backs towards both sides of the legend.

Bulālum has a second seal in which his title, mentioned on the first seal, is omitted. Why he would want to omit his title is not known. From the few traces of the seal scene on his first seal as compared with the remains of the second, it is clear that they were different. The second seal has two filling motifs next to the legend which makes it even more mysterious that the line with the title is omitted. There was certainly enough space for it when the seal was first cut. The filling motifs were added only later, apparently because the seal owner concluded that there was too much blank space left. ${ }^{77}$

77 We say "owner" and not "seal cutter" because both filling motifs were added - at two different moments in time - after the seal had already been in use for some time. This will be discussed in a forthcoming article by G. Suurmeijer. 
Ilabrat-bāni adds his title on his second seal which he starts using between Sa 11 and 13 and uses until AS 6 at the latest (i.e. ten years). What is preserved of his seals suggests that they had quite different scenes.

The sealing pattern

An analysis of the sealing practice shows that this followed the order of the witness lists as far as our group is concerned. We can discern two distinct sealing patterns that follow each other in time.

At first, the order of sealing goes from the upper edge or top of the left edge down over the left edge and onto the lower edge. The second pattern is to seal first the upper edge, then the lower one, and then the left edge. These conclusions are based on a few instances only and should be taken with due caution.

The order of the officials

Two ranking principles operate among the officials of the Šamaš temple in Old Babylonian Sippar witnessing contracts. The first one is linked to the title, the second one to seniority.

The šangûm (first and second) always comes first, followed by the overseer of the naditum priestesses, as soon as these titles appear. There is only one holder of each of these three offices at a time. As to the šangûms it can be observed that a new first šangûm can, for a short time, rank lower in the group than an older second šangûm (this happens outside our time frame here). For the overseer we have seen that, when he takes over from his father, Ibbi-Ilabrat starts at the bottom and then moves up.

After these come the doorkeeper and the chariot drivers, and, occasionally, a courtyard sweeper.

At the beginning of the period under scrutiny, under Immerum and Sumu-la-el, there is a single doorkeeper at a time and he appears in a middle position within the group, under the sanga and the overseer of the nadiātum-priestesses but before the chariot drivers (of whom there can be up to three). Here, too, seniority is at work, as when the doorkeeper Amurrum-bāni starts out low but ascends to occupy the position that his father held before him. At the end of the reign of Suma-la-el and under Sabium we see multiple doorkeepers at the same time (up to three, briefly even four, if we include Šamaš-littul ${ }^{78}$ ). They now occupy a lower position in the lists and are followed by the courtyard sweeper only.

78 After the period that we discuss here, occasionally there are up to five doorkeepers at the same time. 
There seems to be an influx of new doorkeepers who are, as far as we can see, not related to previous ones. Due to seniority they rank lower than the doorkeeper Amurrum-bāni and even lower than the last chariot driver, Adad-rēmēni, who both had inherited their titles from their fathers.

The transition between Damu-galzu and his son Adad-rēmēni, both chariot drivers, is remarkable in that the son immediately occupies the same place in the group as his father did before him, immediately after a doorkeeper. When this doorkeeper, in casu Amurrum-bāni, disappears, Adad-rēmēni will consistently witness after the overseer of the naditum priestesses. He is the last chariot driver of the group, and, under Apil-Sîn, he will become a doorkeeper, followed in this office by his son Kalūmum. From then on the group will consist of the šangûms, the overseer of the naditum priestesses and a number of doorkeepers only.

\section{Bibliography}

Blocher, F. (1992): Siegelabrollungen auf frühaltbabylonischen Tontafeln im British Museum. Ein Katalog. Münchener Vorderasiatische Studien 10. München/Wien.

Charpin, D. (2001): Review of Horsnell 1999, RA 95, 89-92.

Charpin, D. (2004): Histoire politique du Proche-Orient Amorrite (2002-1595), Mesopotamien: Die altbabylonische Zeit. OBO 160/4. Fribourg/Göttingen, 23-480.

Driel, G. van (2002): Elusive silver. In search of a role for a market in an agrarian environment. Aspects of Mesopotamian society. PIHANS 95. Leiden.

Gasche, H. (1998): Dating the fall of Babylon. A reappraisal of second-millennium chronology. Mesopotamian History and Environment Series II: Memoire 4. Ghent/Chicago.

Harris, R. (1975): Ancient Sippar. A Demographic Study of an Old-Babylonian City (18941595 B.C.). PIHANS 36. Istanbul.

Horsnell, M. J. A. (1999): The Year-Names of the First Dynasty of Babylon. Hamilton, Ontario.

Koppen, F. van (2001): Sweeping the court and locking the gate: the palace of Sippir-Sererim, in: W. H. van Soldt et al. (eds.), Veenhof Anniversary Volume. PIHANS 89. Leiden, 211-224.

Sallaberger, W. (2003/4): Schlachtvieh aus Puzriš-Dagān. Zur Bedeutung dieses königlichen Archivs, JEOL 38, 45-62.

Stamm, J. J. (1939): Die akkadische Namengebung. MVAeG 44. Leipzig.

Stol, M./S. P. Vleeming (eds.) (1998): The Care of the Elderly in the Ancient Near East. Studies in the History and Culture of the Ancient Near East 14. Boston/Leiden.

Stol, M. (2000): Titel altbabylonischer Klosterfrauen, in: J. Marzahn /H. Neumann (eds.), Assyriologica et Semitica. Festschrift für Joachim Oelsner. AOAT 252. Münster, 457-466.

Tanret, M. (2010): The Seal of the Sanga. On the Old Babylonian Sangas of Šamaš of Sippar-Jahrūrum and Sippar-Amnānum. Cuneiform Monographs 40. Boston/Leiden.

Teissier, B. (1998): Sealing and Seals: Seal-impressions from the reign of Hammurabi on Tablets from Sippar in the British Museum, Iraq 60, 109-186. 
Wilcke, C. (1983): Nachlese zu A. Poebels Babylonian Legal and Business Documents From the Time of the First Dynasty of Babylon Chiefly from Nippur (BE 6/2) Teil 1, ZA 73, 48-66.

- (1998): Care of the Elderly in Mesopotamia in the Third Millennium BC, in: Stol/ Vleeming (eds.), 23-57. 